\title{
Degradation of Buprofezin in Flooded and Upland Soils under Laboratory Conditions
}

\author{
Shunji Funayama, Matazaemon Uchida, Hideo Kanno* and Katsuo Tsuchiya \\ Institute of Life Science Research, Nihon Nohyaku Co., Ltd., \\ Honda-cho, Kawachinagano 586, Japan \\ *Chemical Research Center, Nihon Nohyaku Co., Ltd., \\ Nishiyodogawa-ku, Osaka 555, Japan
}

(Received May 28, 1986)

\begin{abstract}
[Phenyl ring-U-14 C] buprofezin, 2-tert-butylimino-3-isopropyl-5-phenyl-perhydro-1,3,5thiadiazin-4-one, gradually decomposed in soils under flooded and upland conditions, with the half lives of 104 and 80 days, respectively. After 150 days, five degradation products were identified by thin-layer cochromatography: 2-tert-butylimino-5-(4-hydroxyphenyl)-3isopropyl-perhydro-1,3,5-thiadiadin-4-one, 3-isopropyl-5-phenyl-perhydro-1,3,5-thiadiazin-2,4dione, 1-tert-butyl-3-isopropyl-5-phenyl-biuret, 1-isopropyl-3-phenylurea and phenylurea. As minor products, 2-tert-butylimino-5-phenyl-perhydro-1,3,5-thiadiazin-4-one or buprofezin sulfoxide were found in the flooded or the upland soil. $\quad\left[{ }^{14} \mathrm{C}\right]$ Carbon dioxide and bound ${ }^{14} \mathrm{C}$ residue accounted for $23-24 \%$ and $13-21 \%$ of the applied radioactivity, respectively. The degradation of buprofezin remarkably delayed in sterile soils. Since neither formation of ${ }^{14} \mathrm{CO}_{2}$ nor ring hydroxylation was observed in the sterile soils, buprofezin seems to have undergone complete mineralization in the soils under both flooded and upland conditions through biological transformation by soil microorganisms.
\end{abstract}

\section{INTRODUCTION}

Buprofezin (Applaud ${ }^{\circledR}, 2$ 2-tert-butylimino-3isopropyl-5-phenyl-perhydro-1, 3, 5-thiadiazin4-one) is an insect growth regulator that effectively controls harmful insect pests including the brown rice planthopper, Nilaparvata lugens STÅL, and the greenhouse whitefly, Trialeurodes vaporariorum WESTwood. ${ }^{1-4)} N$. lugens nymphs treated with buprofezin exhibit abnormalities in their ability to shed the exuviae and finally die at the time of molting. ${ }^{3)}$ The compound was recently demonstrated to act on the insects by inhibiting the integumentary cuticle deposition and chitin biosynthesis. ${ }^{5,6)}$ Although no lethal effect of buprofezin on adult insects has been observed, its strong suppression on the egg-laying of $N$. lugens female adults is indicated. ${ }^{7)}$ More recently, the similar effects on the twenty-eight-spotted ladybird, Henosepilachna vigintioctopunctata FABRICIUS, was reported. ${ }^{7,8)}$

Buprofezin is not highly toxic to mammals: acute oral $\mathrm{LD}_{50}$ is over $2000 \mathrm{mg} / \mathrm{kg}$ for rats and mice. ${ }^{1)}$ Because of the high hydrophobicity $(\log P=4.31)$, buprofezin is easily adsorbed with soil particles. ${ }^{9)}$ Strong soil adsorption is sometimes contributed to persistence of the compound in soils. Therefore, the degradability of buprofezin in soils has been studied at our institute and is discussed in the present paper.

\section{MATERIALS AND METHODS}

\section{Compounds}

$\left[\right.$ Phenyl ring-U- $\left.-{ }^{14} \mathrm{C}\right]$ buprofezin was synthesized from $\left[\mathrm{U}-{ }^{14} \mathrm{C}\right]$ aniline hydrogen sulfate (Amersham International, Buckinghamshire, $\mathrm{UK})$ by reacting the intermediate, $N$-chloro- 
Table 1 Authentic compounds and their $R f$ values.

\begin{tabular}{|c|c|c|c|c|c|c|c|c|c|}
\hline \multirow{2}{*}{$\begin{array}{l}\text { Compound } \\
\text { No. }\end{array}$} & $\mathrm{S}$ & cture & & & \multicolumn{5}{|c|}{$\begin{array}{c}R f \text { values } \\
\text { Solvent system } \text { used }^{\text {a })}\end{array}$} \\
\hline & $\mathrm{R}_{1}$ & $\mathrm{R}_{2}$ & $\mathrm{X}$ & $\mathrm{Y}$ & $\mathrm{A}$ & $\mathrm{B}$ & $\mathrm{C}$ & $\mathrm{D}$ & $\mathrm{E}$ \\
\hline $\mathbf{1}^{\mathrm{b})}$ & $\mathrm{CH}\left(\mathrm{CH}_{3}\right)_{2}$ & $\mathrm{~N}-\mathrm{C}\left(\mathrm{CH}_{3}\right)_{3}$ & $\mathrm{H}$ & $\mathrm{S}$ & 0.65 & 0.56 & 0.64 & 0.50 & 0.88 \\
\hline 2 & $\mathrm{CH}\left(\mathrm{CH}_{3}\right)_{2}$ & $\mathrm{~N}-\mathrm{C}\left(\mathrm{CH}_{3}\right)_{3}$ & $\mathrm{OH}$ & $\mathrm{S}$ & 0.31 & 0.38 & 0.41 & 0.18 & 0.61 \\
\hline 3 & $\mathrm{H}$ & $\mathrm{N}-\mathrm{C}\left(\mathrm{CH}_{3}\right)_{3}$ & $\mathrm{H}$ & $\mathrm{S}$ & 0.16 & 0.00 & 0.06 & -c) & 0.28 \\
\hline 4 & $\mathrm{CH}\left(\mathrm{CH}_{3}\right)_{2}$ & $\mathrm{O}$ & $\mathrm{H}$ & $\mathrm{S}$ & 0.62 & 0.42 & 0.56 & 0.31 & 一 \\
\hline 5 & $\mathrm{CH}\left(\mathrm{CH}_{3}\right)_{2}$ & $\mathrm{~N}-\mathrm{C}\left(\mathrm{CH}_{3}\right)_{3}$ & $\mathrm{H}$ & SO & 0.51 & 0.31 & 0.51 & 0.18 & 0.71 \\
\hline & $\mathrm{R}_{3}$ & $\mathrm{R}_{4}$ & & & & & & & \\
\hline 6 & $\mathrm{CH}\left(\mathrm{CH}_{3}\right)_{2}$ & $\mathrm{CONHC}\left(\mathrm{CH}_{3}\right)_{3}$ & & & 0.64 & 0.47 & 0.60 & 0.41 & - \\
\hline 7 & $\mathrm{CH}\left(\mathrm{CH}_{3}\right)_{2}$ & $\mathrm{H}$ & & & 0.46 & 0.32 & 0.43 & 0.15 & 0.53 \\
\hline 8 & $\mathrm{H}$ & $\mathrm{H}$ & & & 0.34 & 0.04 & 0.10 & 0.01 & 0.12 \\
\hline
\end{tabular}

a) Solvent systems used; A: benzene/ethyl acetate/acetic acid (6/2/1), B: diisopropyl ether/ acetone (9/1), C: heptane/ethyl acetate/ethanol/28\% $\mathrm{NH}_{4} \mathrm{OH}(25 / 25 / 5 / 1), \mathrm{D}$ : hexane/ethyl acetate (2/1), E: diisopropyl ether/acetonitrile (9/1).

b) Buprofezin.

c) Not determined.

methyl- $N$ - $\left[\right.$ phenyl $\left.-{ }^{14} \mathrm{C}\right]$ phenylcarbamoyl chloride, with 1-tert-butyl-3-isopropylthiourea. ${ }^{1,10}$ Its specific activity was $6.9 \mathrm{mCi} / \mathrm{mmol}$ and radiochemical purity more than $98 \%$. Authentic compounds in Table 1 were used for identification of degradation products from buprofezin (1). Compound $\mathbf{2}$ was obtained from 2-tert-butylimino-3-isopropyl-5-(4-methoxyphenyl)-perhydro-1,3,5-thiadiazin-4-one by reacting with hydroiodic acid. ${ }^{10)}$ Compound $\mathbf{3}$ and 2-(1,1-dimethyl-2-hydroxyethyl) imino-3isopropyl-5-phenyl-perhydro-1,3,5-thiadiazin4-one (9) were synthesized from $N$-chloromethyl- $N$-phenyl-carbamoyl chloride and the corresponding thioureas. The reaction of compound 9 with hydrochloric acid gave compound 4. Compounds 5 and $\mathbf{6}$ were prepared from buprofezin $(\mathbf{1})$ by reacting with perbenzoic acid and chlorine, respectively. Compounds $\mathbf{7}$ and $\mathbf{8}$ were obtained from the appropriate amines and phenyl isocyanate. ${ }^{11)}$

\section{TLC and Radioassay}

TLC and radioassay were performed according to the methods reported previously. ${ }^{12)}$ Solvent systems and obtained $R f$ values for authentic compounds 1-8 are listed in Table 1 .

\section{Soils and Incubation}

Soils were collected from a paddy and an upland field in Ehime Prefecture. They were passed through a 1-mm sieve and then stored at $-20^{\circ} \mathrm{C}$ until use. The soil analysis data are summarized in Table 2. Each soil (50-250 g of dry weight) was put into a $250-\mathrm{ml}$ widemouthed flask with water. The water content in the soil was adjusted once a week to maintain a flooded condition (with water 1.5 $\mathrm{cm}$ deep) or an upland condition (60\% of the maximum water holding capacity). ${ }^{13)}$ In order to obtain a sterile condition, the soils were autoclaved at $120^{\circ} \mathrm{C}$ for $30 \mathrm{~min}$, and the following procedures such as $\left[{ }^{14} \mathrm{C}\right]$ buprofezin application, aeration and adjustment of water content were performed under the sterile condition. After preincubation at $25^{\circ} \mathrm{C}$ for 2 weeks, $\left[{ }^{14} \mathrm{C}\right]$ buprofezin was added to the flasks to give a final concentration of $1.6 \mathrm{ppm}(0.53$ $\mu \mathrm{Ci} /$ flask $)$ in the flooded soil or $2.5 \mathrm{ppm}(0.82$ $\mu \mathrm{Ci} /$ flask) in the upland soil. The treated soils under the flooded or upland condition were incubated at $25^{\circ} \mathrm{C}$ in the dark. Carbon 
Table 2 Analysis data of soils used.

\begin{tabular}{lccccccccc}
\hline $\begin{array}{c}\text { Soil } \\
\text { (origin) }\end{array}$ & Texture & $\begin{array}{c}\text { Sand } \\
(\%)\end{array}$ & $\begin{array}{c}\text { Silt } \\
(\%)\end{array}$ & $\begin{array}{c}\text { Clay } \\
(\%)\end{array}$ & $\begin{array}{c}\text { Carbon } \\
(\%)\end{array}$ & $\begin{array}{c}\text { Cation } \\
\text { exchange } \\
\text { capacity }\end{array}$ & $\begin{array}{c}\mathrm{pH} \\
100 \mathrm{~g})\end{array}$ & $\begin{array}{c}\text { Maximum } \\
\text { water } \\
\text { holding } \\
\text { capacity } \\
(\%)\end{array}$ \\
\hline $\begin{array}{l}\text { Ehime } \\
\begin{array}{l}\text { (Paddy, } \\
\text { alluvial) }\end{array}\end{array}$ & $\begin{array}{c}\text { Silty clay } \\
\text { loam }\end{array}$ & 23.0 & 63.1 & 13.9 & 3.8 & 11.6 & 6.4 & 4.7 & 72.4 \\
$\begin{array}{l}\text { Ehime } \\
\text { (Upland field, } \\
\text { dilluvial) }\end{array}$ & $\begin{array}{c}\text { Sandy } \\
\text { loam }\end{array}$ & 55.3 & 22.6 & 22.1 & 2.4 & 11.0 & 7.0 & 6.3 & 43.0 \\
\hline
\end{tabular}

dioxide-free air was gently introduced into the flasks and the air from the outlets was passed through urethane foam and $2 \mathrm{~m} \mathrm{NaOH}$ to trap volatile ${ }^{14} \mathrm{C}$-products and ${ }^{14} \mathrm{CO}_{2}$, respectively. These traps and the soils were sampled at various intervals during the 150-day incubation.

\section{Extraction and Analysis of Degradation Products}

The paddy water covering the soil under the flooded condition was separated by decantation. The obtained water was extracted twice with ethyl acetate $(100 \mathrm{ml})$. The soils under the flooded and upland conditions were extracted three times with acetone $(100 \mathrm{ml})$ and then twice with methanol $(100 \mathrm{ml})$. The extracts were combined, concentrated in vacuo and then redissolved in $100 \mathrm{ml}$ of water. The resulting aqueous solution was extracted twice with ethyl acetate $(100 \mathrm{ml})$ at $\mathrm{pH} 7$ and then twice at $\mathrm{pH} 1$. The radioactivity remaining in the soils was finally extracted with $100 \mathrm{ml}$ of methanolic $2 \mathrm{~m} \mathrm{NaOH}$ (methanol/water, 1/3) at $40^{\circ} \mathrm{C}$ overnight. The methanolic alkaline extracts were partitioned with diethyl ether (100 $\mathrm{ml}$ ) at $\mathrm{pH} 14$ and 1 and then combined with the ethyl acetate extracts. The urethane foam traps were extracted with $50 \mathrm{ml}$ of methanol. The radioactivity in the methanol extracts was attributed to $\left[{ }^{14} \mathrm{C}\right]$ buprofezin by thin-layer cochromatography, accounting for $2-7 \%$ of the applied ${ }^{14} \mathrm{C}$. The amount of $\left[{ }^{14} \mathrm{C}\right]$ buprofezin in the methanol extract was registered as that of buprofezin in the soils. Small portions of the obtained organic or aqueous solutions were subjected to radioassay or TLC analysis. The unextractable radioactivity in soils was determined by using a sample oxidizer and liquid scintillation counters. ${ }^{13)}$

The degradation products of buprofezin in the flooded and the upland soils were separated and identified by thin-layer cochromatography with appropriate authentic compounds. Those on TLC plates were analyzed by scraping the autoradiographically detected regions into counting vials and subjected to the subsequent liquid scintillation counting. The ${ }^{14} \mathrm{CO}_{2}$ in $\mathrm{NaOH}$ traps was determined by acidifying with conc. $\mathrm{HCl}$ and trapping the reforming ${ }^{14} \mathrm{CO}_{2}$ with $10 \mathrm{ml}$ of Oxisorb-CO $\mathrm{CO}_{2}$ (New England Nuclear, Boston, USA), followed by liquid scintillation counting. ${ }^{13)}$

\section{RESULTS AND DISCUSSION}

\section{Disappearance of $\left[{ }^{14} \mathrm{C}\right]$ Buprofezin and} ${ }^{14} \mathrm{CO}_{2}$ Formation in Soils

Under the flooded condition, $\left[{ }^{14} \mathrm{C}\right]$ buprofezin gradually decomposed in the soil as shown in Fig. 1. After 150 days, $42 \%$ of the applied buprofezin remained unchanged. From the first-order decreasing line $(\ln Y=-0.0060354 X$ $+4.54023, r=0.966)$, the half life of buprofezin in the flooded soil was estimated as 104 days. Correspondingly, the ${ }^{14} \mathrm{CO}_{2}$ trapped in $2 \mathrm{~m} \mathrm{NaOH}$ increased with time and finally accounted for $24 \%$ of the applied radioactivity after 150 days.

Sterilization of the flooded soil retarded buprofezin decomposition (the extrapolated half life, 432 days) and completely inhibited the evolution of ${ }^{14} \mathrm{CO}_{2}$ (Fig. 1). Even after 150 days, $80 \%$ of $\left[{ }^{14} \mathrm{C}\right]$ buprofezin was recovered from the flooded soil and the ${ }^{14} \mathrm{CO}_{2}$ trapped in $2 \mathrm{~m} \mathrm{NaOH}$ was negligible.

$\left[{ }^{14} \mathrm{C}\right]$ Buprofezin also decreased gradually in the soil under the upland condition (Fig. 1), showing a half life of 80 days (calculated from 

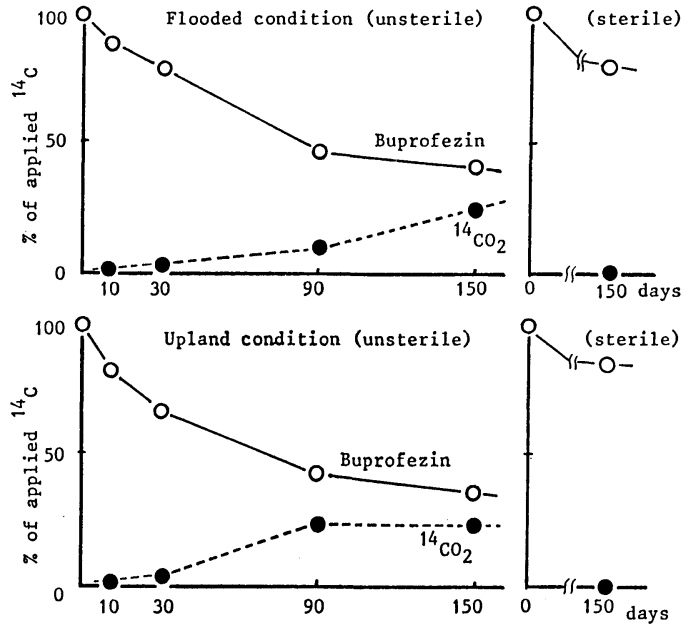

Fig. 1 [Phenyl-14C] buprofezin remaining unchanged in Ehime soils under flooded and upland conditions, and the cumulative ${ }^{14} \mathrm{CO}_{2}$ in $2 \mathrm{M}$ $\mathrm{NaOH}$ trap.

More than $97 \%$ of applied $\left[{ }^{14} \mathrm{C}\right]$ buprofezin was recovered from both soils on the 1st day of incubation according to the methods described in the text.

the first-order decreasing line: $\ln Y=$ $-0.0074596 X+4.50517, r=0.988)$. The formation of ${ }^{14} \mathrm{CO}_{2}$ was observed to be similar to that under the flooded condition, accounting for $23 \%$ of the applied radioactivity after 150 days.

Here again, soil sterilization retarded buprofezin degradation in the soil (the extrapolated half life, 673 days) and completely inhibited the evolution of ${ }^{14} \mathrm{CO}_{2}$ under the upland condition (Fig. 1).

\section{Analysis of Degradation Products}

The degradation products identified by thinlayer cochromatography and their abundance in the soils are shown in Table 3. Most of the extractable radioactivity was attributed to $\left[{ }^{14} \mathrm{C}\right]$ buprofezin even after 150 days. The identified products from the unsterile soils were compounds 2-8 under the flooded condition or compounds $\mathbf{2}$ and $\mathbf{4 - 8}$ under the upland condition. Minor unidentified products were also detected in the soils under both conditions but only accounted for $2-3 \%$ of the applied radioactivity as a whole. The aqueous ${ }^{14} \mathrm{C}$ ( 8.5 or $7.3 \%$ of the radioactivity applied to the flooded or upland soil, respectively) has not been identified yet. The major products were ${ }^{14} \mathrm{CO}_{2}$ and bound ${ }^{14} \mathrm{C}$ residue which accounted for 24.4 and $12.7 \%$ or 23.2 and $20.5 \%$ of the radioactivity applied to the flooded or upland

Table 3 Buprofezin and its degradation products, and their abundance in soils under flooded and upland conditions.

\begin{tabular}{|c|c|c|c|c|}
\hline \multirow{3}{*}{$\begin{array}{l}\text { Buprofezin and } \\
\text { products }\end{array}$} & \multicolumn{4}{|c|}{ Abundance ( $\%$ of applied radioactivity) after 150 days in soils under } \\
\hline & \multicolumn{2}{|c|}{ Flooded condition } & \multicolumn{2}{|c|}{ Upland condition } \\
\hline & Unsterile & Sterile & Unsterile & Sterile \\
\hline Buprofezin (1) & 41.84 & 80.45 & 36.26 & 85.90 \\
\hline Compound 2 & 0.61 & -a) & 0.08 & - \\
\hline 3 & 0.06 & - & - & 一 \\
\hline 4 & 0.22 & 0.83 & 0.18 & trace \\
\hline 5 & trace & - & 0.15 & 0.16 \\
\hline 6 & 0.23 & 0.42 & 0.75 & trace \\
\hline 7 & 0.80 & 1.32 & 1.20 & 0.93 \\
\hline 8 & 0.15 & 0.05 & 0.13 & 0.06 \\
\hline Unidentified & & & & \\
\hline organic soluble & 3.15 & 2.37 & 3.36 & 2.05 \\
\hline Aqueous & 8.50 & 2.92 & 7.30 & 1.73 \\
\hline${ }^{14} \mathrm{CO}_{2}$ & 24.47 & - & 23.21 & - \\
\hline Bound ${ }^{14} \mathrm{C}$ residue & 12.67 & 6.24 & 20.53 & 6.16 \\
\hline Total & 92.70 & 94.60 & 93.15 & 96.99 \\
\hline
\end{tabular}

a) Less than $0.01 \%$. 


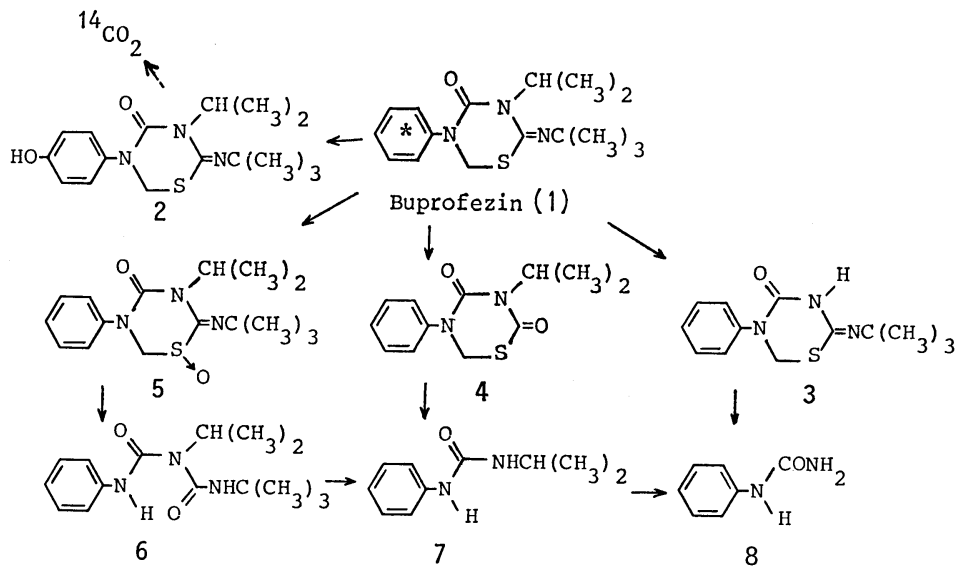

Fig. 2 Proposed pathways of buprofezin degradation in soils under flooded and upland conditions.

* shows the ${ }^{14} \mathrm{C}$ labeled position.

soil, respectively (Table 3 ). The extractable identified and unidentified products were found after 10 or 30 days but did not increase thereafter. Therefore, these products of buprofezin seems to have degraded further to ${ }^{14} \mathrm{CO}_{2}$ or bound ${ }^{14} \mathrm{C}$ residue.

Under the sterile condition, compounds $\mathbf{1}$ and $4-8$ were detected in both the flooded and upland soils (Table 3). However, no formation of compound 2 and ${ }^{14} \mathrm{CO}_{2}$ was observed throughout the experiments under the flooded and upland conditions. These products must have been formed through the biological transformation by soil microorganisms. The aromatic ring-opening process by microorganisms is well established to be operated by a series of oxidative ring hydroxylation reactions. ${ }^{14)}$ The mineralization of buprofezin to ${ }^{14} \mathrm{CO}_{2}$ also seems to undergo through oxidative ring hydroxylation by soil microorganisms, in which compound $\mathbf{2}$ may be the important intermediate.

\section{Pathways of Buprofezin Degradation in Soils}

From the identified degradation products, the pathways of buprofezin degradation in soils under the flooded and upland conditions can be proposed as shown in Fig. 2. As already mentioned, ring hydroxylation occurred only under the unsterile condition, which may be the key step for ${ }^{14} \mathrm{CO}_{2}$ formation. Buprofezin also underwent cleavage of thiadiazinone ring presumably through thiadiazindione (4) or sulfoxide (5). Phenylurea herbicides have been hydrolyzed to their corresponding anilines in soils. ${ }^{15,16)}$ Although phenylureas (7 and 8) were detected as the minor products of buprofezin, no aniline was found in the soils so far.

\section{ACKNOWLEDGMENTS}

The authors thank Dr. Takashi Suzuki and Sayoko Nagaoka for their invaluable discussion and assistance, respectively.

\section{REFERENCES}

1) H. Kanno, K. Ikeda, T. Asai \& S. Maekawa: Proc. 1981 Br. Crop Prot. Conf. Pests and Diseases, Vol. 1, p. 59, 1981

2) O. Kajihara, T. Asai, K. Ikeda \& S. S. Lim: Proc. Conf. Prot. in the Tropics, p. 1, 1982

3) T. Asai, M. Fukada, S. Maekawa, K. Ikeda \& H. Kanno: Appl. Entomol. Zool. 18, 550 (1983)

4) T. Asai, O. Kajihara, M. Fukada \& S. Maekawa: Appl. Entomol. Zool. 20, 111 (1985)

5) M. Uchida, T. Asai \& T. Sugimoto: Agric. Biol. Chem. 49, 1233 (1985)

6) Y. Izawa, M. Uchida, T. Sugimoto \& T. Asai: Pestic. Biochem. Physiol. 24, 343 (1985)

7) M. Yasui, M. Fukada \& S. Maekawa: Appl. Entomol. Zool. 20, 340 (1985)

8) Y. Izawa, M. Uchida \& M. Yasui: Agric. Biol. Chem. 50, 1369 (1986)

9) M. Uchida, H. Nishizawa \& T. Suzuki: $J$. 
Pesticide Sci. 7, 397 (1982)

10) K. Ikeda, H. Kanno \& M. Yasui: "Pesticide Chemistry, Human Welfare and the Environment," ed. by J. Miyamoto \& P. C. Kearney, Vol. 1, Pergamon Press, Oxford, p. 141, 1983

11) B. Hardy: J. Chem. Soc. 1934, 2011

12) N. Murakami, M. Uchida, K. Yabutani, M. Okada \& H. Aizawa: J. Pesticide Sci. 8, 483 (1983)

13) M. Uchida, Y. Ohori, T. Sugimoto \& H. Aizawa: J. Pesticide Sci. 8, 529 (1983)

14) F. Matsumura: "Degradation of Pesticides," ed. by F. Matsumura \& C. R. Krishna Murti, Plenum Press, New York and London, p. 67, 1982

15) J. M. Marvel, B. B. Brightwell, J. M. Malik, M. L. Sutherland \& M. L. Rueppel: J. Agric. Food Chem. 26, 1116 (1978)

16) A. Haque, I. Weisgerber, D. Kotzias \& W. Klein: Pestic. Biochem. Physiol. 7, 321 (1977)

\section{要 約}

\section{Buprofezin の湛水および畑地条件下の容器内土}

\section{壤における分解}

船山俊治，内田又左衛門，菅野英夫，土屋勝夫 [Phenyl 環-14C] buprofezin は土壌(愛媛県で採取)中で 徐々に分解し，その半減期は湛水および畑地条件下でそ れぞれ 104 打よび 80 日と推定された. 同定された 7 分 解物は, phenyl 環の水酸化, イオウの酸化, 脱 tert-butylimino 化打よび thiadiazinone 環の開裂により生成す ると考えられた. 150 日後には, ${ }^{14} \mathrm{CO}_{2}$ および結合型残 留物が，施用 ${ }^{14} \mathrm{C}$ のそれぞれ 23〜24\% および 13〜21\% を占めた。土塨をあらかじめ滅菌しておくと, buprofezinの半減期は著しく延長し（それぞれ 432 および 673 日，外挿値), phenyl 環の水酸化打よび ${ }^{14} \mathrm{CO}_{2}$ の生成が 認められなくなった. したがって, buprofezin $の{ }^{14} \mathrm{CO}_{2}$ への分解には土壌微生物が関与すると考えられた。 